University of Nebraska - Lincoln

DigitalCommons@University of Nebraska - Lincoln

8-16-2021

\title{
Effects of the functional Gpc-B1 allele on soft durum wheat grain, milling, flour, dough, and breadmaking quality
}

Alecia M. Kiszonas

Maria Itria Ibba

Jeffrey D. Boehm Jr

Craig F. Morris

Follow this and additional works at: https://digitalcommons.unl.edu/usdaarsfacpub

Part of the Agriculture Commons

This Article is brought to you for free and open access by the U.S. Department of Agriculture: Agricultural Research Service, Lincoln, Nebraska at DigitalCommons@University of Nebraska - Lincoln. It has been accepted for inclusion in Publications from USDA-ARS / UNL Faculty by an authorized administrator of DigitalCommons@University of Nebraska - Lincoln. 


\title{
Effects of the functional $G p c-B 1$ allele on soft durum wheat grain, milling, flour, dough, and breadmaking quality
}

\author{
Alecia M. Kiszonas ${ }^{1}$ (iD \\ Maria Itria Ibba ${ }^{2}$ (C) \\ Jeffrey D. Boehm Jr. ${ }^{3}$ \\ Craig \\ F. Morris ${ }^{1}$
}

${ }^{1}$ USDA-ARS Western Wheat Quality Laboratory, Washington State University, Pullman, WA, USA

${ }^{2}$ Global Wheat Program, International Maize and Wheat Improvement Center (CIMMYT), Texcoco, Mexico

${ }^{3}$ USDA-ARS Wheat, Sorghum and Forage Research Unit, 251 Filley Hall, University of Nebraska-Lincoln East Campus,

Lincoln, NE, USA

\section{Correspondence}

Alecia M. Kiszonas, USDA-ARS Western Wheat Quality Lab, Pullman, WA, USA.

Email: alecia.kiszonas@usda.gov

Funding information

USDA ARS, Grant/Award Number: CRIS 2090-43440-008-00D and NIFA 2013-67013-21226

\begin{abstract}
Background and objectives: Utilization of durum wheat (Triticum turgidum subsp. durum) can be enhanced by increasing grain and flour protein content. One strategy to increase protein content is by introducing the functional $G p c-B 1$ allele from wild emmer (Triticum turgidum subsp. dicoccoides).

Findings: Introduction of the functional $G p c-B 1$ allele into soft kernel durum increased grain and flour protein by $17 \mathrm{~g} / \mathrm{kg}$, increased dough strength as evidenced by SDS sedimentation volume and Mixograph dough mixing parameters, and increased straight-dough pan bread volume. When grown under arid conditions, high protein $(151 \mathrm{~g} / \mathrm{kg})$ samples had decreased loaf volumes indicative of inelastic doughs. The functional $G p c-B 1$ allele was associated with decreased test weight, a small increase in SKCS hardness, and a modest increase in flour ash; otherwise, milling performance was not affected.

Conclusions: Introgression of the $G p c-B 1$ functional allele from dicoccoides into durum wheat can improve dough strength and breadmaking quality. The effect tends to be consistent over environments but overall, $G p c-B 1$ made only a modest improvement in durum wheat breadmaking quality. Further studies with concomitant selection at other loci are needed to see the effects of Gpc-B1 among elite germplasm.

Significance and novelty: Durum wheat production and consumption will increase as bread quality improves. The functional $G p c-B 1$ allele contributed to improved breadmaking quality. The present report is the first to examine the effect of this allele on breadmaking in durum wheat.

\section{K E Y W O R D S}

bread baking quality, dough strength, durum wheat, gluten, grain protein content $(G p c)$, soft kernel
\end{abstract}

\footnotetext{
Names are necessary to report factually on available data; however, the USDA neither guarantees nor warrants the standard of the product, and the
} use of the name by the USDA implies no approval of the product to the exclusion of other that may also be suitable.

This article is in the public domain and not copyrightable. It may be freely reprinted with customary crediting of the source.

(C) 2021 Cereals \& Grains Association. This article has been contributed to by US Government employees and their work is in the public domain in the USA. 


\section{INTRODUCTION}

Protein content (concentration) is an essential qualitydetermining factor in wheat (Triticum sp.) grain and flour utilization. Protein content is highly influenced by weather, soil nutrients, and agronomic management. Nevertheless, protein content can be increased through phenotypic selection among wheat breeding lines and germplasm. However, few major protein-controlling loci have been identified. In this regard, Avivi (1978) reported that wild emmer (T. turgidum subsp. dicoccoides) (hereafter dicoccoides) had exceptionally high protein, higher than domesticated durum (T. turgidum subsp. durum) and emmer (T. turgidum subsp. dicoccum). This discovery highlights the value and opportunities that reside in wild genetic resources.

Joppa and Cantrell (1990) used one of these high protein dicoccoides lines (FA-15-3 $\equiv$ Israel-A) to create a set of chromosome disomic substitution lines in the durum cultivar cv. "Langdon" (LDN). The 6B dicoccoides substitution line (LDN[DIC-6B]) had the highest grain protein of any of the substitution lines and was significantly higher than Langdon (179.5 versus $167.9 \mathrm{~g} / \mathrm{kg}$, respectively). In a follow-up study, LDN(DIC-6B) sib lines had a mean grain protein content of $174.9 \mathrm{~g} / \mathrm{kg}$ versus $161.7 \mathrm{~g} /$ $\mathrm{kg}$ for Langdon. Further, this grain protein increase was associated with an increase in semolina protein content of $16.2 \mathrm{~g} / \mathrm{kg}$. The LDN(DIC-6B) lines had higher $10-\mathrm{g}$ Mixograph scores and superior spaghetti quality. Steiger et al. (1996) used the LDN(DIC-6B) line of Joppa and Cantrell (1990) to develop a recombinant population with the durum cv. Vic. The LDN(DIC-6B)/Vic population had significantly higher mean protein than the control Langdon/Vic population (159.0 versus $155.6 \mathrm{~g} \mathrm{~kg}^{-1}$ ). SDS sedimentation volumes, however, did not differ. Kovacs et al. (1998) also used the LDN(DIC-6B) line of Joppa and Cantrell (1990) to develop a recombinant population with the recurrent Canadian durum parent "DT367." In general, $\mathrm{BC}_{2}$-derived lines were higher in protein than DT367 and had higher SDS sedimentation values, higher Mixograph total energy, and superior pasta quality. Klindworth et al. (2009) and Ohm et al. (2010) compared the quality of the LDN(DIC-6B) line of Joppa and Cantrell (1990) with similar 6B substitution lines developed using dicoccoides lines PI 481,521 and PI 478,742 (LDN521 and LDN742, respectively). Of the three, LDN(DIC-6B) and LDN742 had significantly higher grain and semolina protein content than Langdon, while only LDN742 had a better (higher) Mixograph score. Grain protein differences compared with Langdon ranged from -0.1 (ns) to $20.2 \mathrm{~g} / \mathrm{kg}(p<.05)$. Molecular marker analysis indicated that LDN742 carried the Grain protein content-B1 ( $G p c$ B1) alleles such as LDN(DIC-6B) whereas LDN521 did not (Langdon allele). Molecular marker analysis of parents PI 481521 and PI 478742 for $G p c-B 1$ was consistent with these results. In Ohm et al. (2010), the dicoccoides chromosome 6B in LDN(DIC-6B) and LDN742 was associated with greater quantity of size-exclusion HPLC fractions comprised of high-molecular-weight polymeric protein and $\omega$-gliadins compared with Langdon, and higher Mixograph scores. Brevis and Dubcovsky (2010) developed two pairs of $\mathrm{BC}_{6}$ near-isogenic lines (NILs) ( \pm Gpc-B1) using a LDN(DIC-6B) derivative ("RSL 65"). The durum breeding line UC1113 and the cv. Kofa were used as recurrent parents. The Gpc-B1 NILs with the functional allele had significantly higher grain protein content compared with the NILs lacking a functional $G p c-B 1$ (in 2005, 136.2 versus $132.1 \mathrm{~g} / \mathrm{kg}$ and in 2006-2007, 146.5 versus $132.7 \mathrm{~g} / \mathrm{kg}$ ). Brevis et al. (2010) produced an additional pair of NILs in the durum cv. Kronos and included them with the UC1113 NILs, above. The presence of the functional $G p c-B 1$ allele was associated with higher grain protein content and wet gluten, longer Mixograph mixing time and peak height, and improved spaghetti quality. Salmanowicz et al. (2017) used the LDN(DIC-6B) line of Joppa and Cantrell (1990) and compared it to Langdon over three environments: $\mathrm{N}$ deficit, water deficit, and control. The grain protein content, wet gluten, and Zeleny sedimentation volume of LDN(DIC-6B) were significantly higher than Langdon under all three environments. LDN(DIC-6B) also had greater Rheometer area under the curve, peak time, peak height, and bandwidth after $10 \mathrm{~min}$, and greater $R_{\max }$, extensibility and $W_{\max }$ on the Keiffer system compared with Langdon under all three environments. Tab bita et al. (2017) reviewed 25 studies involving $G p c-B 1$ conducted over 10 years. In all eleven studies comparing grain protein content, the functional allele of $G p c-B 1$ significantly increased grain protein (mean protein content over studies was $155 \mathrm{~g} / \mathrm{kg}$ ). Further details of individual studies are provided above. Fatiukha et al. (2020) used a durum cv. Svevo $\times$ dicoccoides Y12-3 recombinant inbred line (RIL) population to confirm the chromosome 6B short arm (6BS) location of $G p c-B 1$. Like most commercial durum cultivars, Svevo lacked the $G p c$ $B 1$ functional allele for higher protein.

No study to date has examined the effect of $G p c-B 1$ on breadmaking in durum wheat. This is likely because first, most durum utilization is focused on pasta, and secondly, that durum has not been viewed as having gluten properties well suited for bread (Morris, 2021). This latter view is not entirely borne out by research (Ammar et al., 2000; Edwards et al., 2007; Hernández-Espinosa et al., 2019; Murray et al., 2017). A secondary factor influencing the lack of research on the effect of $G p c-B 1$ on the breadmaking quality of durum wheat is the very hard kernel of durum. The hard kernel texture of durum 
precludes milling durum grain into flour without an unacceptably high increase in starch damage and a marked increase in dough water absorption (Dexter et al., 1981; Murray et al., 2016). However, with the advent of soft kernel durum wheat (Morris et al., 2011), this confounding issue has been eliminated (Boehm et al., 2017a; Murray et al., 2017). Here, we examine the effects of the introgression of the functional allele of $G p c-B 1$ into soft durum wheat grain, milling, flour, dough, and breadmaking quality.

\section{MATERIALS AND METHODS}

"Soft Svevo" (Morris et al., 2011) was crossed with Desert King-High Protein (Desert King HP, PVPP 201000585) (experimental line UC1627, pedigree UC1113-GPV(PI 638741)/6*Desert King), which carries the $G p c-B 1$ functional allele derived from wild emmer (dicoccoides). In 2016, the progeny $\left(\mathrm{F}_{4: 6}\right)$ RILs were grown as single rows at Yuma, AZ, and at the Washington State University Dryland Research Station near Lind, WA, and in 2017 at the Spillman Agronomy Farm near Pullman, WA. The 2017 samples were grown in replicated plots with two replications for all RILs and the two parents. These fullsib RILs were developed as follows. Beginning at the $\mathrm{F}_{3}$, kernels were visually inspected and only nonvitreous (i.e., soft) kernels were selected to be advanced via single seed descent. The same process was repeated in the $\mathrm{F}_{4}$, resulting in 30 soft $\mathrm{F}_{6}$ lines, 15 of which carried the functional $G p c-B 1$ allele from Desert King-High Protein and 15 that carried the nonfunctional Svevo allele at the same locus.

The presence of the functional $G p c-B 1$ allele was confirmed in the $\mathrm{F}_{5}$ generation using the codominant molecular marker Xuhw89 developed by Distelfeld et al. (2006). Specifically, leaf tissue from $\mathrm{F}_{5}$ plants was collected for genomic DNA and extracted using the DNeasy 96 Plant Kit (Qiagen). PCRs were carried out in $25 \mu$ reaction volumes containing 100 ng of genomic DNA, 1x Standard Taq Buffer (New England Biolabs), $200 \mu \mathrm{M}$ dNTPs, $0.2 \mu \mathrm{M}$ primers, and $0.5 \mu \mathrm{l}$ of Taq DNA Polymerase (New England Biolabs). Amplifications were performed in a Peltier Thermal Cycler PTC-200 using an annealing temperature of $57^{\circ} \mathrm{C}$. PCR products with the fluorescent label were diluted 1:8 in water, and $3 \mu \mathrm{l}$ of the dilution was added to $9 \mu \mathrm{l}$ of HiDi Formamide and $0.5 \mu \mathrm{l}$ of $500-\mathrm{Liz}^{\mathrm{TM}}$ internal size standard (Applied Biosystems). The mixtures were denatured at $95^{\circ} \mathrm{C}$ for $10 \mathrm{~min}$ and separated by capillary electrophoresis using a 3130xl DNA Analyzer (Applied Biosystems). The allele size of the PCR products was determined by using the GeneMarker software v3.7 (SoftGenetics).

Test weight, Single Kernel Characterization System (SKCS) kernel hardness, grain protein, flour protein, modified
Quadrumat milling, flour ash, and flour Na-dodecyl sulfate (SDS) sedimentation volume were conducted according to Kiszonas et al. (2013). Straight-dough pan bread baking was conducted according to Kiszonas et al. (2015).

Mixograph parameters provided an assessment of dough strength and a prediction of breadmaking potential. "Mixograph time to peak" is the time in minutes required to mix the flour and water dough to the optimum condition for bread baking to the point of minimum dough mobility. This time is evidenced by the "peak" of the mixing curve (Chung et al., 2001). With an optimally hydrated dough, the highest point of the midline Mixograph mixing curve is defined as the "Mixograph time to peak"; the height of the curve at this point is the "Mixograph peak height." "Mixograph work" is the integration of the area under the midline of the mixing curve from time zero to the peak. Lastly, "Mixograph curve width 2 min after peak" is self-explanatory and is related to resistance to overmixing. Mixograph parameters were determined using the Mixsmart software (Mixsmart for Windows version 1.0.404, Lincoln, NE).

Analysis of variance was conducted using a factorial model including genotype (equivalent to the presence or absence of the functional $G p c-B 1$ allele), location (representing the individual environments), and the interaction term. Statistical significance of whole models and components thereof were evaluated using the $F$ test at alpha $=0.05$. Individual recombinant inbred lines represented replicates. Trait means were calculated for each allele group and tested for significance using the least significant difference (alpha $=0.05$ ).

\section{3 | RESULTS AND DISCUSSION}

The durum variety Desert King-High Protein (DKHP) is a popular "desert durum" adapted to the Southwest United States and carries the functional allele of $G p c-B 1$ (hereafter referred to as $G p c$-B1-plus). DKHP was crossed with Soft Svevo, a soft kernel durum variety, to evaluate the effects of $G p c-B 1$ on grain quality, the protein content of grain and flour, milling, flour, dough, and breadmaking quality of soft durum. Soft Svevo carries the nonfunctional allele of $G p c-B 1$ (hereafter referred to as $G p c-B 1$-minus). After the initial cross was made, only soft-textured kernels were selected, that is, those that carried the puroindolinecontaining Hardness translocation from the D genome (Boehm et al., 2017; Ibba et al., 2019). For example, the average SKCS hardness value for all genotypes planted in the study was 22.0. All lines were $\mathrm{F}_{4}$-derived full sibs and can be considered soft-textured RILs. For quality and statistical analyses, the progeny was divided into two allele groups: Gpc-B1-plus and $G p c-B 1$-minus. 
TA B LE 1 Analysis of variance of grain and milling quality of soft durum wheat sibling lines with or without introgression of $G p c-B 1$ grown at three locations

\begin{tabular}{|c|c|c|c|c|c|c|c|}
\hline Source & $\begin{array}{l}\text { Test } \\
\text { weight }\end{array}$ & $\begin{array}{l}\text { SKCS } \\
\text { hardness }\end{array}$ & $\begin{array}{l}\text { Wheat } \\
\text { protein }\end{array}$ & Flour yield & $\begin{array}{l}\text { Break flour } \\
\text { yield }\end{array}$ & $\begin{array}{l}\text { Milling } \\
\text { score }\end{array}$ & $\begin{array}{l}\text { Flour } \\
\text { ash }\end{array}$ \\
\hline Whole model $R^{2}$ & 0.84 & 0.30 & 0.79 & 0.30 & 0.35 & 0.21 & 0.30 \\
\hline$G p c-B 1 F$ value & $328.5^{* * *}$ & $15.4^{* * *}$ & $92.1^{* * *}$ & 0.17 & 0.54 & $12.3^{* * *}$ & $15.1^{* * *}$ \\
\hline Location $F$ value & $146.9^{* * *}$ & $28.7^{* * *}$ & $308.6^{* * *}$ & $23.2^{* * *}$ & $33.2^{* * *}$ & $8.2^{* *}$ & $29.2^{* * *}$ \\
\hline
\end{tabular}

${ }^{*} 0.05-0.01 . ; * * 0.01-0.001 . ; * *<0.001$.

TA B LE 2 Analysis of variance of flour, dough, and baking quality of soft durum wheat sibling lines with or without introgression of Gpc-B1 grown at three locations

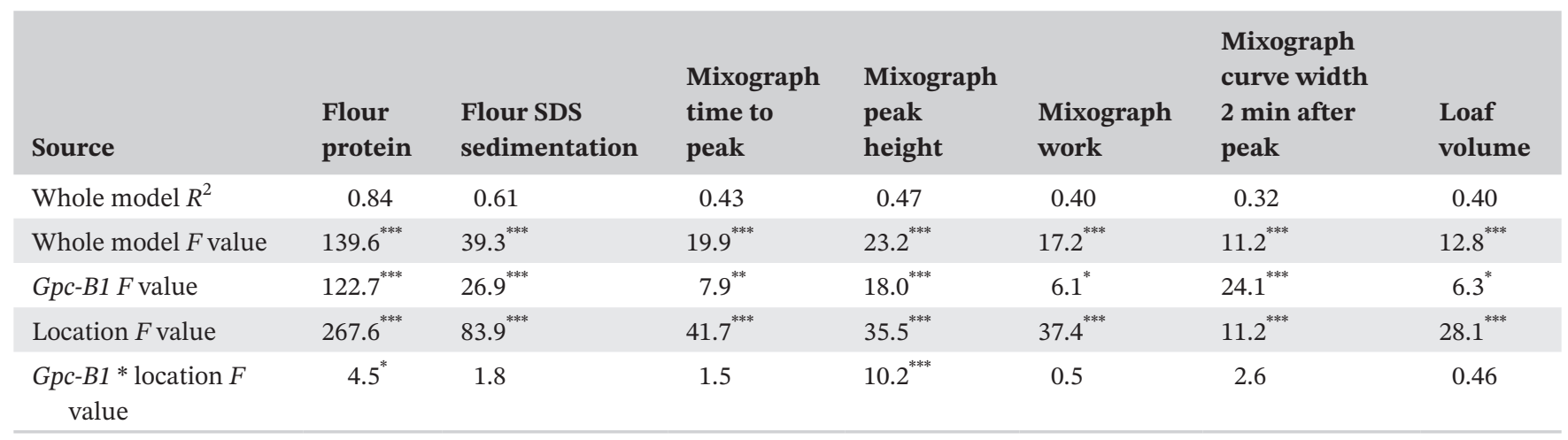

*0.05-0.01.; **0.01-0.001.; ***<0.001.

TA B LE 3 Mean separation of grain and milling quality soft durum wheat sibling lines with or without introgression of $G p c-B 1$, and location of production

\begin{tabular}{|c|c|c|c|c|c|c|c|}
\hline Variable & $\begin{array}{l}\text { Test weight } \\
\left(\mathrm{kg} \cdot \mathrm{hL}^{-1}\right)\end{array}$ & $\begin{array}{l}\text { SKCS } \\
\text { hardness }\end{array}$ & $\begin{array}{l}\text { Wheat protein } \\
\left(\mathrm{g} \cdot \mathrm{kg}^{-1}\right)\end{array}$ & $\begin{array}{l}\text { Flour yield } \\
\left(\mathrm{g} \cdot \mathrm{kg}^{-1}\right)\end{array}$ & $\begin{array}{l}\text { Break flour } \\
\text { yield }\left(\mathrm{g} \cdot \mathrm{kg}^{-1}\right)\end{array}$ & $\begin{array}{l}\text { Milling } \\
\text { score }\end{array}$ & $\begin{array}{l}\text { Flour } \\
\text { ash } \\
\left(\mathrm{g} . \mathrm{kg}^{-1}\right)\end{array}$ \\
\hline $\begin{array}{l}G p c-B 1 \\
\text { minus }\end{array}$ & 79.3 & 20.1 & 145 & 647 & 427 & 70.3 & 5.1 \\
\hline Lind & 77.5 & 24.8 & 165 & 643 & 426 & 67.6 & 5.5 \\
\hline Spillman & 77.4 & 19.1 & 138 & 635 & 407 & 70.3 & 5.0 \\
\hline Yuma & 80.5 & NA & NA & 671 & 463 & NA & NA \\
\hline LSD & 0.4 & 2.1 & 3 & 10 & 14 & 1.7 & 0.2 \\
\hline
\end{tabular}

Note: SKCS hardness, wheat protein, milling score, and flour ash from only 2017.

Abbreviations: NA, not available; NS, not significant.

Overall, the analysis of variance modeled the variation in the study moderately well (Tables 1 and 2), with test weight, and wheat and flour protein contents having $R^{2}$ values of $0.79-0.84$. Other traits were modeled less well, although all models had significant whole model
$F$-values. $G p c-B 1$ allele status was significant for test weight, SKCS hardness, wheat protein, milling score, flour ash, flour protein, SDS sedimentation volume, the four Mixograph parameters, and bread loaf volume. Only flour yield and break flour yield were not significantly 


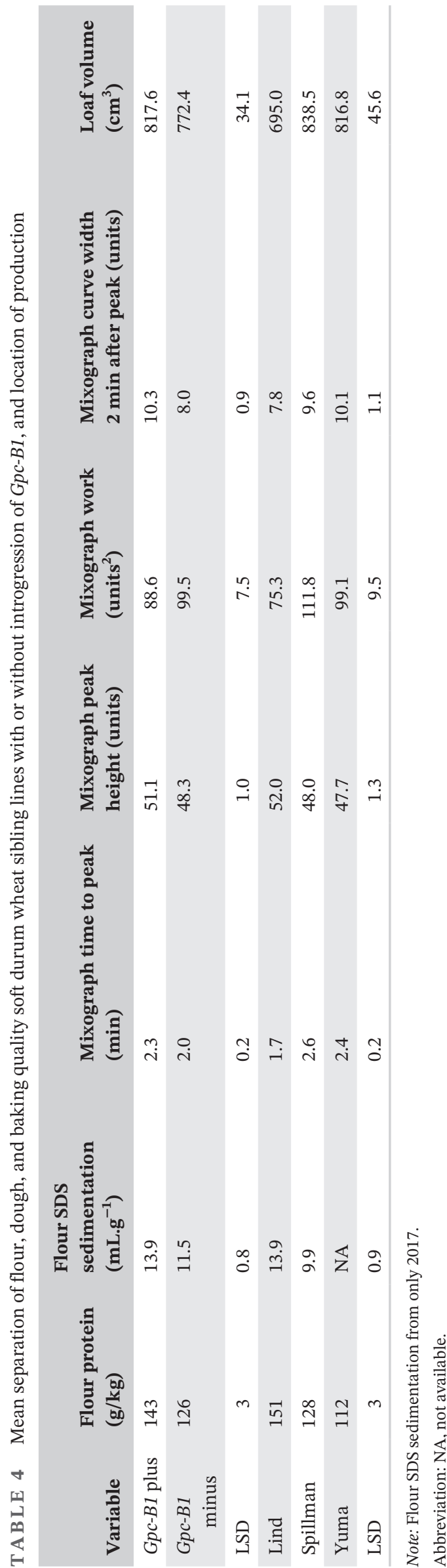

influenced by $G p c-B 1$ allele. Nevertheless, location was almost always a more influential source of variation compared with $G p c-B 1$ allele. The only exceptions were test weight, milling score, and Mixograph curve width 2 min after peak. There were interactions between $G p c$ $B 1$ allele and location for several parameters, though their $F$-values, and thus relative contribution to overall variation, were greatly eclipsed by the main effects. The results indicate that $G p c-B 1$ exerts a significant effect on most grain, flour, dough, and breadmaking traits, but less so for milling performance. Overall, environmental influences, though usually greater than that of the $\mathrm{Gpc}$ $B 1$ allele, were consistent across the study (small interactions). As such, the $G p c-B 1$-plus allele has significant and predictable effects. The actual effects on quality are detailed following.

Tables 3 and 4 present the mean values for each sets of RILs with and without the functional $G p c-B 1$ allele, and for the three growing environments. The $G p c-B 1$ plus lines had lower test weight and harder textured kernels. Joppa et al. (1991) reported a significant reduction in test weight associated with the dicoccoides chromosome 6B, whereas Klindworth et al. (2009) and Ohm et al. (2010) found no effect. The recombinant dicoccoides 6B in Brevis et al. (2010) was associated with reduced test weight.

Wheat (grain) protein content was significantly higher in the $G p c$-B1-plus lines, 160 versus $145 \mathrm{~g} / \mathrm{kg}$, respectively. These values are equivalent to the average of eleven studies summarized by Tab bita et al. (2017), which showed a $15.5 \mathrm{~g} / \mathrm{kg}$ average increase in protein content due to the functional $G p c-B 1$ allele.

Flour yield and break flour yield did not differ significantly according to $G p c-B 1$ allele status, despite the difference in test weight. Although not the same as soft wheat milling in the present study, Joppa et al. (1991) reported a reduction in semolina and total milling extraction due to the dicoccoides chromosome 6B. Klindworth et al. (2009), however, found no effect of $6 \mathrm{~B}$ on semolina extraction or ash content. Ohm et al. (2010) similarly found no effect of $6 \mathrm{~B}$ on semolina yield, but semolina ash was higher in the Gpc-B1-plus lines. Brevis et al. (2010) also reported increased semolina ash for $G p c$-B1-plus recombinants. In the present study, flour ash content was significantly higher in the Gpc-B1-plus lines (Table 3). Milling score, a composite score that includes flour ash, was significantly lower for the $G p c-B 1$-plus lines, likely due to the higher flour ash.

Flour protein content paralleled grain protein closely (Tables 3 and 4), with greater mean flour protein levels for the $G p c-B 1$-plus lines (143 versus $126 \mathrm{~g} / \mathrm{kg}$ ). The difference $(17 \mathrm{~g} / \mathrm{kg})$ was identical to the difference in average grain protein between the two sets of RILs. 
SDS sedimentation volume has long been used as a predictor of dough strength in durum wheat (Dick \& Quick, 1983). Here, the Gpc-B1-plus RILs had greater SDS sedimentation volume compared with $G p c$-B1-minus RILs (Table 4). However, SDS sedimentation volume is responsive to flour protein (Carter et al., 1999) and the $17 \mathrm{~g} / \mathrm{kg}$ greater average protein among the $G p c$-B1-plus RILs likely was the primary reason for the higher SDS sedimentation volume. Steiger et al. (1996) found no significant difference between sets of progeny comparing LDN(DIC-6B)/ Vic and control Langdon/Vic. Kovacs et al. (1998) stated that the average sedimentation volume of $\mathrm{BC}_{2}$ recombinant lines with $G p c$-B1-plus was greater than the recurrent durum parent.

Dough mixing strength was generally greater in the Gpc-B1-plus RILs compared with the Gpc-B1-minus lines as evidenced by an increased Mixograph time to peak, Mixograph peak height, and Mixograph curve width $2 \mathrm{~min}$ after peak (Table 4). This difference in mixing strength was particularly prominent in the curve width 2 min after peak. There was a 2.3 unit greater Mixograph curve width 2 min after peak indicating greater resistance to overmixing in the Gpc-B1-plus RILs. Despite the improved strength and resistance to overmixing of the $G p c-B 1$-plus lines, the Mixograph work, or area under the Mixograph curve, was lower for the Gpc-B1-plus lines. This decrease in work could indicate that the dough was less elastic and could not stretch sufficiently because of the extra protein. Joppa et al. (1991) found that the dicoccoides 6B chromosome increased Mixograph score, whereas Klindworth et al. (2009) and Ohm et al. (2010) found that two different dicoccoides 6B chromosomes (both with functional $G p c-B 1$ ) had significant (increased) and nonsignificant effects on Mixograph score, respectively. Kovacs et al. (1998) indicated that the average Mixograph total energy of $\mathrm{BC}_{2}$ recombinant lines with $G p c$-B1-plus was greater than the recurrent durum parent. Brevis et al. (2010) reported an increase of $0.3 \mathrm{~min}(12 \%)$ in Mixograph peak mixing time and a similar $13 \%$ increase in peak height due to Gpc-B1-plus.
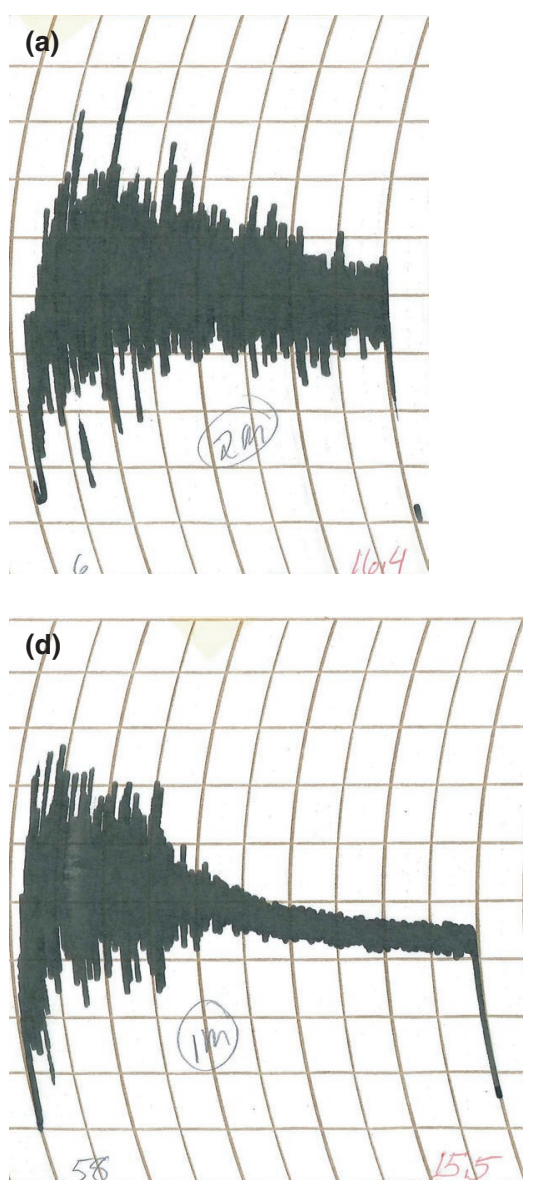
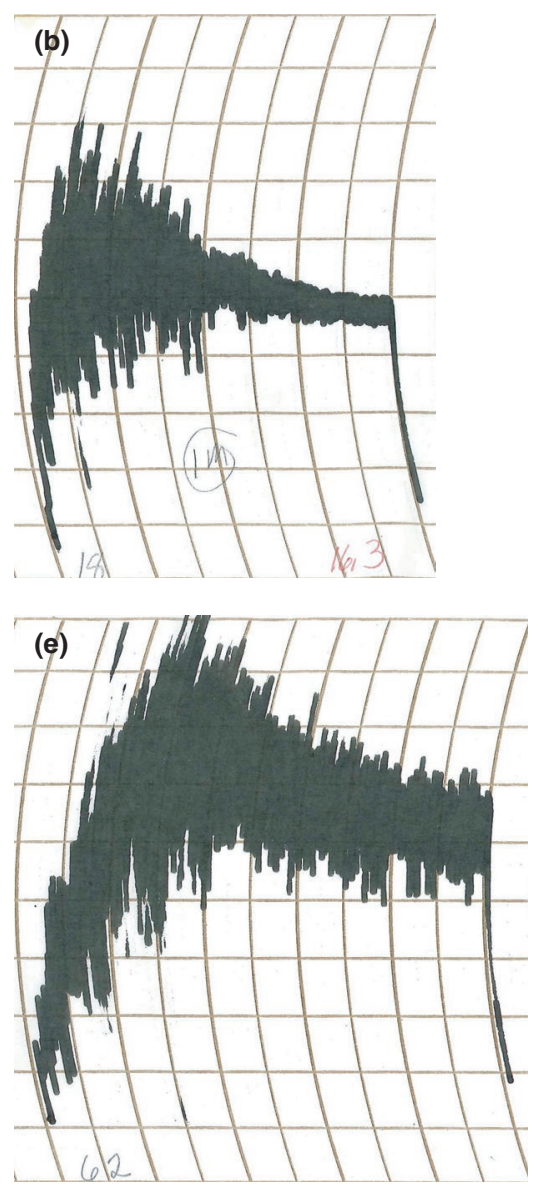
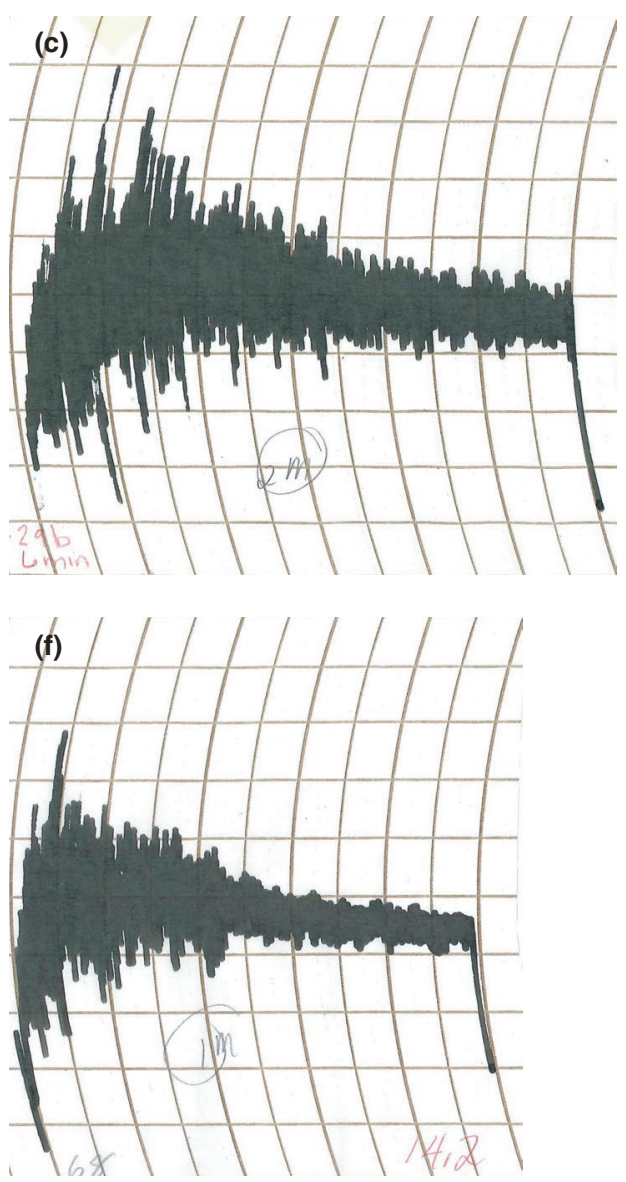

F I G U RE 1 Mixograms of soft kernel durum full-sib recombinant inbred lines (RILs) and their parents (a) a Gpc-B1-plus RIL with $167 \mathrm{~g} / \mathrm{kg}$ flour protein and the largest $\left(870 \mathrm{~cm}^{3}\right)$ loaf volume for that allele class; (b) a $G p c-B 1$-plus RIL with $163 \mathrm{~g} / \mathrm{kg}$ flour protein and the smallest $\left(600 \mathrm{~cm}^{3}\right)$ loaf volume for that allele class; (c) a $G p c-B 1$-minus RIL with $144 \mathrm{~g} / \mathrm{kg}$ flour protein and the largest (875 $\left.\mathrm{cm}^{3}\right) 10 a f$ volume for that allele class; (d) a $G p c$-B1-minus RIL with $155 \mathrm{~g} / \mathrm{kg}$ flour protein and the smallest ( $505 \mathrm{~cm}^{3}$ ) loaf volume for that allele class; (e) Desert King-High Protein (Gpc-B1-plus) with $186 \mathrm{~g} / \mathrm{kg}$ flour protein and a $785 \mathrm{~cm}^{3}$ loaf volume; and (f) Soft Svevo (Gpc-B1-minus) with $142 \mathrm{~g} / \mathrm{kg}$ flour protein and a $575 \mathrm{~cm}^{3}$ loaf volume 
Representative Mixograms are presented in Figure 1. From a visual inspection of the Mixograph curves, especially from the higher protein location of Lind, there was considerable variation among the fifteen RILs comprising each $G p c-B 1$ allele class. Indeed, this within-allele variation was greater than the effect of $G p c-B 1$ allele alone. Nevertheless, $G p c-B 1$ did contribute in a positive way to dough strength regardless. RILs with $G p c-B 1$-plus typically had those Mixograph parameters (see above; Table 4) that contribute to better breadmaking ability.

On this last point, bread loaf volume was significantly greater, on average by $45.2 \mathrm{~cm}^{3}$, for the $G p c-B 1$-plus RILs, 817.6 versus $772.4 \mathrm{~cm}^{3}$. This is the first report of the effect of $G p c-B 1$ on breadmaking quality in durum wheat or soft durum wheat. More generally, breadmaking studies in durum wheat are limited (Boehm et al., 2017b; Kiszonas et al., 2021; Morris, 2021; Morris et al., 2015; Murray et al., 2017). Clearly, by referring to the Mixograms (Figure 1) and the corresponding bread loaf volumes (see figure caption), there is considerable contribution of the parent, with DKHP providing superior breadmaking alleles (probably high and low molecular weight glutenins) in addition to the effect of the functional $G p c-B 1$ allele. "Desert King" possesses Glu-B1 Bx6+By8, Glu-A3 subunit 6, and $G l u-B 2$ subunit 12, whereas "Svevo" possesses Glu$B 1 \mathrm{Bx} 7+\mathrm{By} 8, \mathrm{Glu}-\mathrm{A} 3$ subunits $6+11$, and is null at Glu-B2 (Magallanes-López et al., 2017). Both lines possess allele a at Glu-B3 (Magallanes-López et al., 2017). Irrespective of kernel texture (very hard or soft kernel), there are dramatic differences among durum lines and progeny for bread baking quality, viz. loaf volume. In this regard, the average improvement $\left(45.2 \mathrm{~cm}^{3}\right)$ in bread loaf volume was considerably less than the range within allele class which was 270 and $370 \mathrm{~cm}^{3}, G p c-B 1$-plus, and $G p c-B 1$-minus, respectively (see Figure 1 caption).

Ohm et al. (2010) indicated that the increased protein content associated with the $G p c-B 1$ dicoccoides $6 \mathrm{~B}$ chromosome was related to increases in HPLC fractions described as high- and low-molecular-weight polymeric proteins, and $\alpha-, \beta-, \gamma-$, and $\omega$-gliadins, both in the SDS soluble and insoluble fractions. This general broad-spectrum increase in proteins representing a large number of genes is likely due to the transcriptional regulation of the underlying TtNAM-B1 (Triticum turgidum No Apical Meristem) gene (Uauy et al., 2006). Although not measured here, Brevis et al. (2010) observed increased wet gluten but not gluten index with $G p c$-B1-plus plants. Salmanowicz et al. (2017) also observed an increase in wet gluten across three contrasting environments with the functional $G p c-B 1$ allele.

Briefly, the environments used here, although markedly different, all produced consistent responses from $\mathrm{Gpc}$ $B 1$ (Tables 3 and 4), although the environmental effects were usually larger than that of $G p c-B 1$ allele alone. Lind is a dry location ( $<30 \mathrm{~cm}$ of annual precipitation) and produced greater wheat and flour protein levels. Spillman is a higher precipitation environment $(>51 \mathrm{~cm}$ annual precipitation), and Yuma, AZ, was an irrigated location. These differences were evident in the flour protein content, which decreased with increasing water availability. Test weight was greatest at Yuma, which corresponded to the greatest flour yield and break flour yield from that location compared with the nonirrigated locations. The notably high flour protein level at Lind $(151 \mathrm{~g} / \mathrm{kg}$ ) likely led to doughs that were too stiff and not extensible enough. This lack of extensibility is apparent in the low Mixograph time to peak, Mixograph work, Mixograph curve width $2 \mathrm{~min}$ after peak, and loaf volume. These characteristics are all signs of "bucky" dough, or dough that is too elastic and not extensible enough to allow for sufficient oven spring, and thus, the bread has a smaller loaf with a tight crumb.

Despite the fact that the $G p c-B 1$-plus lines had overall better dough mixing characteristics, they still would not be considered adequate when compared to a typical US hard red spring wheat variety used for making bread (Morris, 2021; Murray et al., 2017). Under the exact same testing protocols, the loaf volume of the hard red spring wheat variety Expresso was $1,050 \mathrm{~cm}^{3}$ at $13.4 \%$ flour protein (Murray et al., 2017). Loaf volume was on average $45.2 \mathrm{~cm}^{3}$ greater in the Gpc-B1-plus lines as compared to the $G p c-B 1$ minus lines. However, recent work (Kiszonas et al., 2021) indicates that introgression of Glu-D1 Dx2+Dy12 highmolecular-weight glutenins can markedly improve breadmaking performance. It will be of considerable interest to combine the Gpc-B1-plus allele with Glu-D1 Dx2+Dy12, in the presence of soft kernel texture (Pina-D1a/Pinb-D1a). We are also evaluating the effects of $\mathrm{Glu}-\mathrm{Blal}\left(\mathrm{Bx} 7^{\mathrm{OE}}\right)$ on dough rheology and breadmaking performance.

\section{\begin{tabular}{l|l}
4 & CONCLUSIONS
\end{tabular}}

Overall, there were some advantages to the introgression of the functional dicoccoides $G p c-B 1$ allele into soft durum. Grain and flour protein contents were increased, dough mixing strength was increased, and bread loaf volumes increased. However, test weight decreased and flour ash increased. This introgression was not sufficient to elevate dough and breadmaking quality to a level commensurate with high-quality bread wheats, but it did make a consistent and positive contribution.

\section{ORCID}

Alecia M. Kiszonas (iD https://orcid.org/0000-0002-0801-2036 Maria Itria Ibba (D) https://orcid.org/0000-0002-3263-0301 Jeffrey D. Boehm Jr. (D) https://orcid.org/0000-0003-2255-5181 Craig F. Morris (D) https://orcid.org/0000-0003-0311-2449 


\section{REFERENCES}

Ammar, K., Kronstad, W. E., \& Morris, C. F. (2000). Breadmaking quality of selected durum wheat genotypes and its relationship with high molecular weight glutenin subunits allelic variation and gluten protein polymeric composition. Cereal Chemistry, 77, 230-236. https://doi.org/10.1094/CCHEM.2000.77.2.230

Avivi, L. (1978). High grain protein content in wild tetraploid wheat Triticum dicoccoides Korn. In S. Ramanujam (Ed.), Proceedings of the $5^{\text {th }}$ International Wheat Genetics Symposium (pp. 372380). Indian Society of Genetics \& Plant Breeding.

Boehm, J. D. Jr, Ibba, M. I., Kiszonas, A. M., \& Morris, C. F. (2017a). End-use quality of CIMMYT-derived soft-kernel durum wheat germplasm: I. Grain, milling, and soft wheat quality. Crop Science, 57, 1475-1484. https://doi.org/10.2135/crops ci2016.09.0774

Boehm, J. D. Jr, Ibba, M. I., Kiszonas, A. M., \& Morris, C. F. (2017b). End-use quality of CIMMYT-derived soft-kernel durum wheat germplasm: II. Dough strength and pan bread quality. Crop Science, 57, 1485-1494. https://doi.org/10.2135/crops ci2016.09.0775

Boehm, J. D. Jr, Zhang, M., Cai, X., \& Morris, C. F. (2017). Molecular and cytogenetic characterization of the 5DS-5BS chromosome translocation conditioning soft kernel texture in durum wheat. Plant Genome, 10, 1-11. https://doi.org/10.3835/plantgenom e2017.04.0031

Brevis, J. C., \& Dubcovsky, J. (2010). Effects of the chromosome region including the grain protein content locus $G p c-B 1$ on wheat grain and protein yield. Crop Science, 50, 93-104.

Brevis, J. C., Morris, C. F., Manthey, F., \& Dubcovsky, J. (2010). Effect of the grain protein content locus $G p c-B 1$ on bread and pasta quality. Journal of Cereal Science, 51, 357-365. https://doi. org/10.1016/j.jcs.2010.02.004

Carter, B. P., Morris, C. F., \& Anderson, J. A. (1999). Optimizing the SDS sedimentation test for end-use quality selection in a soft white and club wheat breeding program. Cereal Chemistry, 76, 907-911. https://doi.org/10.1094/CCHEM.1999.76.6.907

Chung, O. K., Ohm, J. B., Caley, M. S., \& Seabourn, B. W. (2001). Prediction of baking characteristics of hard winter wheat flours using computer-analyzed mixograph parameters. Cereal Chemistry, 78, 493-497. https://doi.org/10.1094/ CCHEM.2001.78.4.493

Dexter, J. E., Matsuo, R. R., Preston, K. R., \& Kilborn, R. H. (1981). Comparison of gluten strength, mixing properties, baking quality and spaghetti quality of some Canadian durum and common wheats. Canadian Institute of Food Science and Technology Journal, 14, 108-111. https://doi.org/10.1016/S0315 $-5463(81) 72720-2$

Dick, J. W., \& Quick, J. S. (1983). A modified screening test for rapid estimation of gluten strength in early-generation durum wheat breeding lines. Cereal Chemistry, 60, 315-318.

Distelfeld, A., Uauy, C., Fahima, T., \& Dubcovsky, J. (2006). Physical map of the wheat high-grain protein content gene Gpc-B1 and development of a high-throughput molecular marker. New Phytologist, 169, 753-763.

Edwards, N. M., Preston, K. R., Paulley, F. G., Gianibelli, M. C., McCaig, T. N., Clarke, J. M., Ames, N. P., \& Dexter, J. E. (2007). Hearth bread baking quality of durum wheat varying in protein composition and physical dough properties. Journal of the Science of Food and Agriculture, 87, 2000-2011. https://doi. org/10.1002/jsfa.2932

Fatiukha, A., Filler, N., Lupo, I., Lidzbarsky, G., Klymiuk, V., Korol, A. B., Pozniak, C., Fahima, T., \& Krugman, T. (2020). Grain protein content and thousand kernel weight QTLs identified in a durum $\mathrm{x}$ wild emmer wheat mapping population tested in five environments. Theoretical and Applied Genetics, 133, 119-131.

Hernandez-Espinosa, N., Payne, T., Huerta-Espino, J., Cervantes, F., Gonzalez-Santoyo, H., Ammar, K., \& Guzman, C. (2019). Preliminary characterization for grain quality traits and high and low molecular weight glutenins subunits composition of durum wheat landraces from Iran and Mexico. Journal of Cereal Science, 88, 47-56. https://doi.org/10.1016/j.jcs.2019.05.007

Ibba, M. I., Zhang, M., Cai, X., \& Morris, C. F. (2019). Identification of a conserved ph1b-mediated 5Ds-5Bs crossing over site in softkernel durum wheat (Triticum turgidum subsp. durum) lines. Euphytica, 215, 200. https://doi.org/10.1007/s10681-019-2518-y

Joppa, L. R., \& Cantrell, R. G. (1990). Chromosomal location of genes for grain protein content of wild tetraploid wheat. Crop Science, 30, 1059-1064. https://doi.org/10.2135/cropsci1990.0011183X00 $3000050021 x$

Joppa, L. R., Hareland, G. A., \& Cantrell, R. G. (1991). Quality characteristics of the Langdon durum-dicoccoides chromosome substitution lines. Crop Science, 31, 1513-1517.

Kiszonas, A. M., Fuerst, E. P., Luthria, D., \& Morris, C. F. (2015). Tracking arabinoxylans through the preparation of pancakes. Cereal Chemistry, 92, 37-43. https://doi.org/10.1094/CCHEM-03-14-0042-R

Kiszonas, A. M., Fuerst, E. P., \& Morris, C. F. (2013). A comprehensive survey of soft wheat grain quality in U.S. germplasm. Cereal Chemistry, 90, 47-57. https://doi.org/10.1094/CCHEM -06-12-0073-R

Kiszonas, A. M., Ibba, M. I., Boehm, J. D. Jr, \& Morris, C. F. (2021). Effects of Glu-D1 gene introgressions on soft white spring durum wheat (Triticum turgidum ssp. durum) quality. Cereal Chemistry, 98, 1112-1122.

Klindworth, D. L., Hareland, G. A., Elias, E. M., Faris, J. D., Chao, S., $\& \mathrm{Xu}, \mathrm{S}$. S. (2009). Agronomic and quality characteristics of two new sets of Langdon durum-wild emmer wheat chromosome substitution lines. Journal of Cereal Science, 50, 29-35. https:// doi.org/10.1016/j.jcs.2009.02.003

Kovacs, M. I. P., Howes, N. K., Clarke, J. M., \& Leisle, D. (1998). Quality characteristics of durum wheat lines deriving high protein from a Triticum dicoccoides (6B) substitution. Journal of Cereal Science, 27, 47-51. https://doi.org/10.1006/ jcrs.1997.0144

Magallanes-Lopez, A. M., Ammar, K., Morales-Dorantes, A., Gonzalez-Santoyo, H., Crossa, J., \& Guzman, C. (2017). Grain quality traits of commercial durum wheat varieties and their relationships with drought stress and glutenins composition. Journal of Cereal Science, 75, 1-9. https://doi.org/10.1016/j. jcs.2017.03.005

Morris, C. F. (2021). Bread baking quality and the effects of Glu-D1 gene introgressions in durum wheat (Triticum turgidum ssp. durum). Cereal Chemistry. (in press, accepted 29 August 2021).

Morris, C. F., Casper, J., Kiszonas, A. M., Fuerst, E. P., Murray, J., Simeone, M. C., \& Lafiandra, D. (2015). Soft kernel durum wheat-a new bakery ingredient? Cereal Foods World, 60, 7683. https://doi.org/10.1094/CFW-60-2-0076 
Morris, C. F., Simeone, M. C., King, G. E., \& Lafiandra, D. (2011). Transfer of soft kernel texture from Triticum aestivum to durum wheat, Triticum Turgidum Ssp. durum. Crop Science, 51, 114-122.

Murray, J. C., Kiszonas, A. M., \& Morris, C. F. (2017). Influence of soft kernel texture on the flour, water absorption, rheology, and baking quality of durum wheat. Cereal Chemistry, 94, 215-222. https://doi.org/10.1094/CCHEM-06-16-0163-R

Murray, J. C., Kiszonas, A. M., Wilson, J., \& Morris, C. F. (2016). Effect of soft kernel texture on the milling properties of soft durum wheat. Cereal Chemistry, 93, 513-517. https://doi. org/10.1094/CCHEM-06-15-0136-R

Ohm, J. B., Klindworth, D. L., Hareland, G. A., Faris, J. D., Elias, E. M., \& Xu, S. S. (2010). Variation in kernel characteristics and protein molecular weight distribution of Langdon durum-wild emmer wheat chromosome substitution lines. Journal of Cereal Science, 52, 207-214. https://doi.org/10.1016/j.jcs.2010.05.007

Salmanowicz, B. P., Langner, M., Mrugalska, B., Ratajczak, D., \& Gorny, A. G. (2017). Grain quality characteristics and dough rheology properties in Langdon durum-wild emmer wheat chromosome substitution lines under nitrogen and water deficits. Journal of the Science of Food and Agriculture, 97, 2030-2041.
Steiger, D. K., Elias, E. M., \& Cantrell, R. G. (1996). Evaluation of lines derived from wild emmer chromosome substitutions. I. Quality traits. Crop Science, 36, 223-227. https://doi.org/10.2135/crops ci1996.0011183X003600020001x

Tabbita, F., Pearce, S., \& Barneix, A. J. (2017). Breeding for increased grain protein and micronutrient content in wheat: Ten years of the Gpc-B1 gene. Journal of Cereal Science, 73, 183-191. https:// doi.org/10.1016/j.jcs.2017.01.003

Uauy, C., Distelfeld, A., Fahima, T., Blechl, A., \& Dubcovsky, J. (2006). A NAC gene regulating senescence improves grain protein, zinc, and iron content in wheat. Science, 314, 1298-1301. https://doi.org/10.1126/science.1133649

How to cite this article: Kiszonas, A. M., Ibba, M. I., Boehm, J. D. Jr., \& Morris, C. F. (2021). Effects of the functional $G p c-B 1$ allele on soft durum wheat grain, milling, flour, dough, and breadmaking quality. Cereal Chemistry, 00, 1-9. https://doi. org/10.1002/cche.10477 